\title{
The topoisomerase II inhibitor, genistein, induces G2/M arrest and apoptosis in human malignant glioma cell lines
}

\author{
FRIEDERIKE SCHMIDT ${ }^{1}$, CHRISTIANE B. KNOBBE ${ }^{1}$, BRIGITTE FRANK ${ }^{1}$, \\ HARTWIG WOLBURG ${ }^{2}$ and MICHAEL WELLER ${ }^{1}$
}

\author{
${ }^{1}$ Department of General Neurology, Hertie Institute for Clinical Brain Research, University of Tuebingen, \\ Hoppe-Seyler-Str. 3; ${ }^{2}$ Institute of Pathology, University of Tuebingen, School of Medicine, Tuebingen, Germany
}

Received November 5, 2007; Accepted December 28, 2007

\begin{abstract}
The protein tyrosine kinase inhibitor, genistein, has been reported to inhibit proliferation and to induce cell death in various non-solid and solid cancer cell lines. Herein, we examined the effects of genistein in several human malignant glioma cell lines. We found that genistein inhibited the proliferation of LN-18, LNT-229, LN-308 and T98G cells at $\mathrm{EC}_{50}$ concentrations of $25-80 \mu \mathrm{M}$ (72 $\mathrm{h}$ of exposure). The growth of a non-neoplastic immortalized human astrocyte cell line, SV-FHAS, was inhibited at similar concentrations. There was a reduction in $\left[{ }^{3} \mathrm{H}\right]$-methylthymidine incorporation and a moderate lactate dehydrogenase release as a sign of cell death in genistein-treated glioma cells. Electron microscopy showed morphological changes with mitochondrial swelling and apoptosis in glioma cells treated with high concentrations of genistein. Genistein-induced cytotoxicity was associated with an increased DNA/topoisomerase II complex formation. Furthermore, genistein induced cell cycle arrest in G2/M. There was an increase in the p53 and p21 levels in response to genistein. However, there was no difference in genistein sensitivity between p21-deficient colon carcinoma cells and isogenic control cells. Genistein-induced cell death in LN-18 and LNT-229 was unaffected by the ectopic expression of the preferential caspase 1/8 inhibitor, crm-A, or co-exposure to the pan-specific pseudosubstrate caspase inhibitor, zVAD-fmk. The ectopic expression of the anti-apoptotic BCL-2 protein attenuated the cytotoxic effects of genistein. Moreover, the ectopic expression of temperature-sensitive $\mathrm{p} 53^{\mathrm{V} 135 \mathrm{~A}}$, which acts as a dominant-negative p53 mutant at $38.5^{\circ} \mathrm{C}$ but assumes p53 wild-type properties at $32.5^{\circ} \mathrm{C}$, in LN-18 or LNT-229 cells, had no effect on genistein cytotoxicity at either temperature.
\end{abstract}

Correspondence to: Dr Friederike Schmidt, Department of General Neurology, Hertie Institute for Clinical Brain Research, University of Tuebingen, Medical School, Hoppe-Seyler-Str. 3, D-72076 Tuebingen, Germany

E-mail: friederike.schmidt@uni-tuebingen.de

Key words: glioma, apoptosis, genistein, isoflavones, differentiation
Genistein did not act in synergy with CD95 ligand-induced apoptosis or various cancer chemotherapy drugs in cytotoxic or clonogenic cell death assays. Thus, genistein-like protein kinase inhibitors are promising agents for the experimental treatment of malignant gliomas.

\section{Introduction}

The prognosis for patients with malignant glioma is still poor, despite aggressive multimodality treatment with surgery, radiotherapy and chemotherapy. Alternative options such as differentiation agents without systemic toxicity in combination with chemotherapeutic agents may lead to better tumor cell killing in these patients. Herein, we examined the effects on the human malignant glioma cell lines of genistein, an isoflavone which is known to induce apoptosis in various tumor cell types. Epidemiological studies suggest that soy consumption may contribute to lower rates of malignancies. Genistein, a major component of soy, has been reported to inhibit the growth of various cultured cancer cell lines such as breast cancer, lymphoma, prostate, lung and colon cancer, and melanoma cells (1-6). Genistein has been proposed to act as a protein tyrosine kinase and topoisomerase II inhibitor, inducer of differentiation and inhibitor of angiogenesis in various nonglial cell lines $(1,5-7)$. Khoshyomn et al (8) showed synergistic effects of BCNU and genistein in U87 and C6 glioma cells. The precise mechanisms by which genistein exerts its effects are still unclear. In the present study, we enquired whether genistein induces differentiation or exerts antiproliferative or apoptotic activity in glioma cells. We also tried to elucidate possible mechanisms of growth inhibition mediated by genistein in malignant glioma cells.

\section{Materials and methods}

Chemicals and reagents. Genistein was obtained from Sigma (St. Louis, MO), diluted at $10 \mathrm{mM}$ in DMSO, and stored in small aliquots at $-20^{\circ} \mathrm{C}$. Cisplatin and cytarabine were obtained from Sigma (St. Louis), CCNU was obtained from Medac (Hamburg, Germany), teniposide from Bristol (Munich, Germany) and topotecan from SmithKline Beecham (King of Prussia, PA). zVAD-fmk and zDEVD-fmk were obtained from Bachem (Heidelberg, Germany). All reagents were 
stored in aliquots at $-20^{\circ} \mathrm{C}$. A soluble CD95L was obtained from murine CD95L cDNA-transfected N2A neuroblastoma cells (9).

Cell lines. LN-18, LNT-229, T98G and LN-308 cells were kindly provided by Dr N. de Tribolet (Lausanne, Switzerland). The cell lines were maintained in DMEM containing 10\% fetal calf serum (FCS), $1 \%$ glutamine and antibiotics (10). The generation of glioma cell sublines expressing murine BCL-2 or murine $\mathrm{p} 53^{\mathrm{V} 135 \mathrm{~A}}$ proteins or the viral caspase inhibitor, crm-A has been described (11-13). The transgene expression was assessed by immunoblotting for murine BCL-2 and $\mathrm{p} 53$ protein and by Northern blot analysis for crm-A mRNA. Experiments were performed in parallel with the control transfectants harbouring plasmids without any insert (neo for BCL-2, hygro for p53 and puro for crm-A). SV-FHAS SV40-transformed human astrocytes were kindly provided by A. Muruganandam (National Research Council, Ottawa, Canada). The p21 $1^{+/+}$ (HCT116) and p21/- (HCT116, no. 80S4) human colon carcinoma cells were kindly provided by B. Vogelstein (14).

Viability assays. For acute cytotoxicity assays, the glioma cells were seeded at $5 \times 10^{3}$ cells/well in 96-well plates, allowed to attach for $24 \mathrm{~h}$ and subsequently exposed to the drugs for $72 \mathrm{~h}$. For clonogenic survival assays, the cells were seeded at $5 \times 10^{2}$ cells/well in 96-well plates, allowed to attach for $24 \mathrm{~h}$ and exposed to the drugs for 10-20 days. Survival and growth were measured by the crystal violet assay. For lactate dehydrogenase $(\mathrm{LDH})$ release, the cells were incubated with the drugs for $72 \mathrm{~h}$ in 96 -well plates. The supernatant $(100 \mu \mathrm{l})$ was transferred to a microtiter plate, incubated for $10 \mathrm{~min}$ at room temperature and light-protected with $100 \mu 1$ of the reaction mixture (Cytotoxicity detection kit/LDH, Boehringer, Mannheim, Germany). Absorbance was measured at $492 \mathrm{~nm}$. For $\left[{ }^{3} \mathrm{H}\right]$-methylthymidine incorporation, the glioma cells were seeded at $5 \times 10^{3}$ cells/well in 96-well plates and allowed to attach for $24 \mathrm{~h}$. After treatment with the drugs for $72 \mathrm{~h}, 1 \mu \mathrm{C}$ of $\left[{ }^{3} \mathrm{H}\right]$-methylthymidine was added per well for $16 \mathrm{~h}$. Then the supernatant was discarded and $50 \mu 1$ trypsin/well was added for $10 \mathrm{~min}$ at $37^{\circ} \mathrm{C}$ prior to harvesting.

Cell cycle analysis. For cell cycle analysis, the glioma cells were exposed to the drugs for 24,48 or $72 \mathrm{~h}$, washed, detached from the culture dishes, harvested, washed and fixed with $70 \%$ ice-cold ethanol. The cells $\left(10^{6}\right.$ per condition) were stained with propidium iodide $(50 \mu \mathrm{g} / \mathrm{ml})$ in phosphate-buffered saline, containing $100 \mu \mathrm{g} / \mathrm{ml}$ RNase A, washed and subjected to flow cytometry of the DNA content using a BectonDickinson FACsCalibur cytometer. The percentages of the cell cycle distribution were calculated by CellQuest software (Becton-Dickinson, Heidelberg, Germany).

Immunoblotting. The levels of p53, p21, BCL-2 or B-actin were examined by immunoblotting as previously described (15).

Determination of the cleavable DNA topoisomerase II complexes. The cleavable DNA topoisomerase II complex formation was assessed as previously described (16). Briefly, the cells were DNA-labeled with $2 \mu \mathrm{Ci} / \mathrm{ml}$ [methyl- $\left.{ }^{3} \mathrm{H}\right]-$
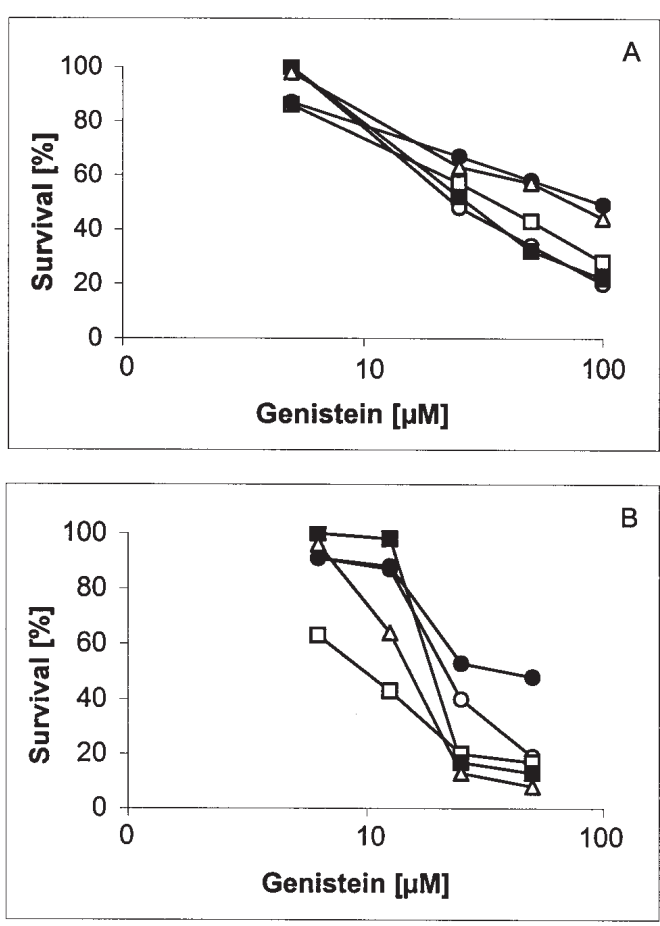

C
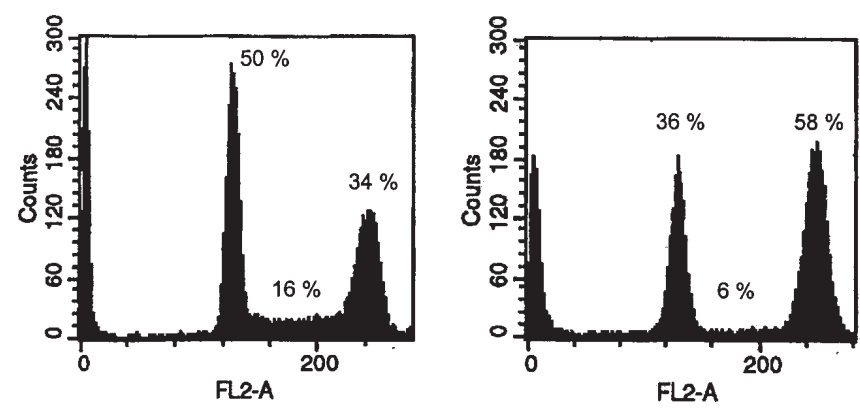

Figure 1. (A and B) Modulation of viability and clonogenicity of human malignant glioma cells and astrocytes by genistein. LN-18 (white circles), LNT-229 (white squares), LN-308 (black circles), T98G (black squares) glioma cells or SVFHAS human astrocytes (white triangles) were exposed to genistein at a high density for $72 \mathrm{~h}\left(10^{4}\right.$ cells/well) (A), or for 10-20 days at a low density $\left(5 \times 10^{2}\right.$ cells/well) (B). Data are expressed as mean percentages of the viable cells relative to the vehicle-treated control cultures $(n=3$, SEM $<10 \%)$ derived from optical densities assessed by crystal violet staining. (C) The induction of cell cycle arrest by genistein. LNT-229 cells were untreated (left panel) or exposed to genistein $(100 \mu \mathrm{M})$ for $24 \mathrm{~h}$. Cell cycle analysis was performed by flow cytometry.

thymidine (specific activity: $20-40 \mathrm{Ci} / \mathrm{mmol}$ ) overnight, adjusted to $100,000 \mathrm{cpm} / \mathrm{ml}$, incubated for a further $24 \mathrm{~h}$, treated with genistein or teniposide for $30 \mathrm{~min}$, washed with PBS and lysed with $1 \mathrm{ml}$ prewarmed $\left(65^{\circ} \mathrm{C}\right)$ lysis solution (1.25\% SDS, 5 mM EDTA, pH 8.0 and herring sperm DNA, $0.4 \mathrm{mg} / \mathrm{ml}$ ). After the shearing of the chromosomal DNA by repeated passing through a 22 -gauge needle, the lysates were transferred to a reaction tube containing $250 \mu 1325 \mathrm{mM}$ $\mathrm{KCl}$, vortexed vigorously, incubated for $10 \mathrm{~min}$ on ice, and centrifuged for $10 \mathrm{~min}$ at $13,000 \mathrm{rpm}$ at $4^{\circ} \mathrm{C}$. The pellets were re-suspended in $1 \mathrm{ml}$ washing solution $(10 \mathrm{mM}$ Tris- $\mathrm{HCl}$, $\mathrm{pH} 8.0,100 \mathrm{mM} \mathrm{KCl}, 1 \mathrm{mM}$ EDTA and $0.1 \mathrm{mg} / \mathrm{ml}$ herring sperm DNA) and kept at $65^{\circ} \mathrm{C}$ for $10 \mathrm{~min}$. The suspensions 

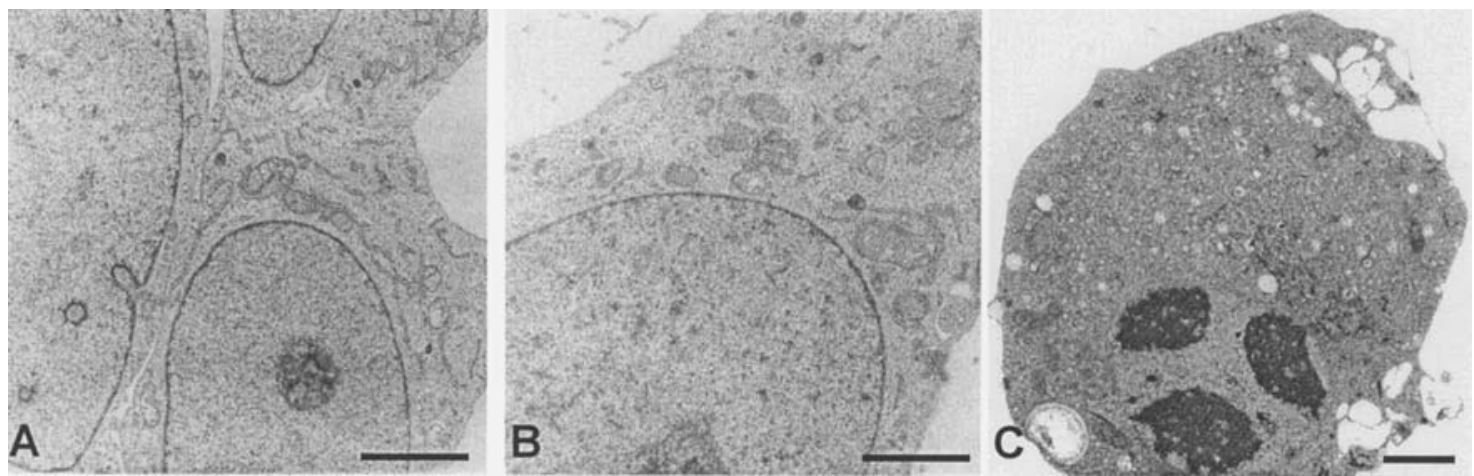

Figure 2. Genistein promotes apoptosis and mitochondria swelling. LNT-229 cells were untreated (A) or exposed to genistein at 5 (B) or $100 \mu \mathrm{M}$ (C) for $72 \mathrm{~h}$; bars, $2 \mu \mathrm{m}$.

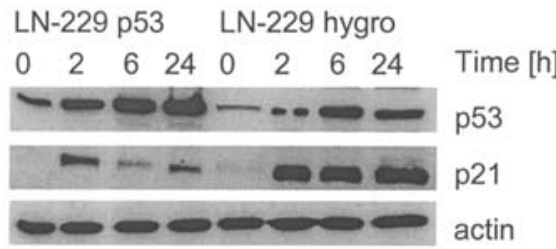

Figure 3. Genistein promotes the p53 and p21 protein accumulation. LNT229 hygro or LNT-229 p53 $3^{\mathrm{V} 135 \mathrm{~A}}$ cells were untreated or exposed to genistein $(100 \mu \mathrm{M})$ for 2,6 or $24 \mathrm{~h}$ at $38.5^{\circ} \mathrm{C}$. Immunoblotting for $\mathrm{p} 53$ and $\mathrm{p} 21$ was performed.

were cooled on ice for $10 \mathrm{~min}$ and re-centrifuged. The pellets were washed and re-suspended in $200 \mu 1 \mathrm{H}_{2} \mathrm{O}\left(65^{\circ} \mathrm{C}\right)$. Radioactivity was measured in a Wallac Liquid Scintillation Counter. The cleavable complex formation was expressed as an $x$-fold increase over the control (untreated cells).

Electron microscopy. For transmission electron microscopy glioma cells and astrocytes treated as indicated were fixed for 60 min at $4^{\circ} \mathrm{C}$ with a solution containing $2.5 \%$ glutaraldehyde in $0.1 \mathrm{M}$ cacodylate buffer. Adherent monolayer cells were scraped off the dish and pelleted by low-speed centrifugation. The pellet was post-fixed with $1 \%$ osmium tetroxide in $0.1 \mathrm{M}$ cacodylate buffer, dehydrated stepwise in ethanol and embedded in Aradite (Serva, Heidelberg, Germany). In 70\% ethanol, the pellets were bloc-stained in saturated uranyl acetate. Ultrathin sections were produced on an FCR Reichert ultracut ultramicrotome (Leica, Bensheim, Germany), mounted on pioloform-coated copper grids, contrasted with uranyl acetate and lead citrate and were examined with an EM-10 (Carl Zeiss, Oberkochen, Germany).

Statistical analysis. $\mathrm{EC}_{50}$ values for drug-induced cell death at $72 \mathrm{~h}$ were assessed by linear regression analysis. Synergy was assessed by the fractional product method (17) and by isobologram analysis.

\section{Results}

The effects of genistein on viability and cell cycle progression of human malignant glioma cells. LN-18, LNT-229, LN-308 and T98G human malignant glioma cells were treated with genistein for $72 \mathrm{~h}$ at a high density or for 10-20 d at a low density. Astrocytes (SV40FHAS) were examined for comparison. Cytotoxic and antiproliferative effects were seen within $72 \mathrm{~h}$ at $\mathrm{EC}_{50}$ concentrations of $25-80 \mu \mathrm{M}$. LN-18, LNT-229 and T98G cells were more sensitive than the LN308 and SV40FHAS cells (Fig. 1A). Upon long-term exposure and at a low density, there was a concentration-dependent growth inhibition at lower (LN-18, LNT-229, LN-308 and SV40FHAS) or similar (T98G) concentrations as in shortterm assays (Fig. 1B). These effects were associated with cell cycle arrest in G2/M (Fig. 1C), a concentration-dependent reduction in $\left[{ }^{3} \mathrm{H}\right]$-methylthymidine incorporation and a moderate induction of the LDH release in LNT-229 and T98G cells (data not shown), suggesting that genistein induces antiproliferative effects with cell cycle arrest as well as cytotoxic effects.

The morphological effects of genistein in glioma cells. To clarify whether morphological features of apoptosis were induced by genistein, we analyzed the morphology of LNT229 cells at 24 and $72 \mathrm{~h}$ after exposure to genistein (5 or $100 \mu \mathrm{M}$ ) by electron microscopy (Fig. 2). The higher concentration of genistein induced apoptosis and morphological changes of the mitochondria with swelling whereas the lower, subtoxic concentration had no effect on the morphology.

Increased expression of p53 and p21 after treatment with genistein. We then sought to assess the role of p53 in genistein-mediated growth inhibition of the glioma cells by studying the p53 wild-type LNT-229 cell line and a transfected cell line expressing dominant-negative p53 ${ }^{\mathrm{V} 135 \mathrm{~A}}$. Notably, there was a time-dependent increase in $\mathrm{p} 53$ expression in the LNT-229 hygro and LNT-229 p53 ${ }^{\mathrm{v} 135 \mathrm{~A}}$ cell lines treated with genistein $(100 \mu \mathrm{M})$. Furthermore, p21 expression was induced by genistein $(100 \mu \mathrm{M})$ in LNT-229 hygro cells at $38.5^{\circ} \mathrm{C}$. This effect was also observed in LNT-229 cells expressing dominant-negative p53, albeit to a lesser degree, suggesting that the induction of p21 by genistein was partly p53-independent (Fig. 3). However, by using p21-deficient colon carcinoma cells and isogenic control cells it was shown that the loss of p21 had no effect on the genistein-induced inhibition of proliferation (data not shown). 


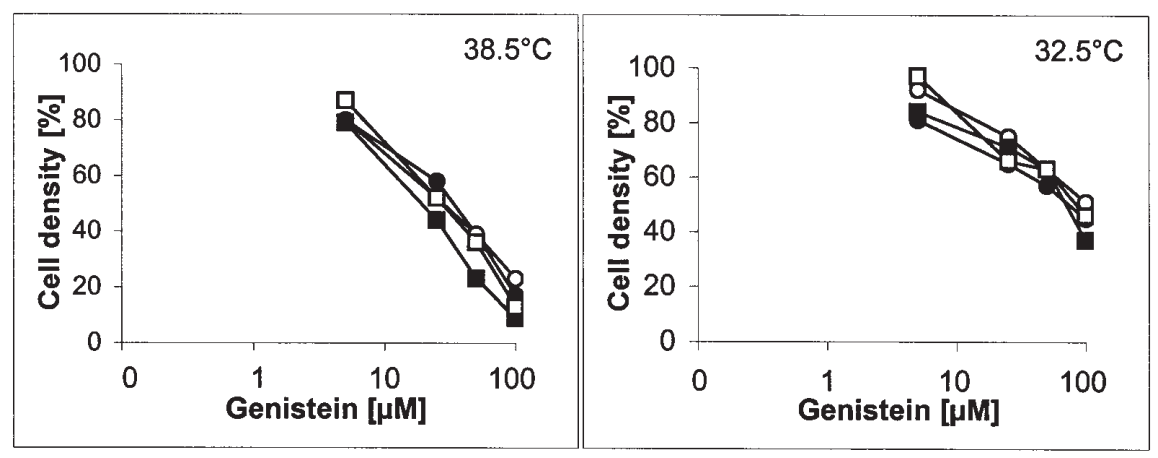

Figure 4. Genistein-induced effects in glioma cells are independent of the p53 conformation. Hygro control (white symbols) or p53 ${ }^{\mathrm{V} 135 \mathrm{~A}}$-transfected (black symbols) LNT-229 (circles) or LN-18 (squares) cells were seeded in 96-well plates (5x10 ${ }^{3}$ cells/well), allowed to attach for $24 \mathrm{~h}$ at $38.5^{\circ} \mathrm{C}$, and then kept at $38.5^{\circ} \mathrm{C}$ (mutant p53, left panel) or shifted to $32.5^{\circ} \mathrm{C}$ (wild-type p53, right panel) for $4 \mathrm{~h}$, and then exposed to genistein for $72 \mathrm{~h}$. Data are expressed as mean percentages of cell density $(n=3$, SEM $<10 \%)$.

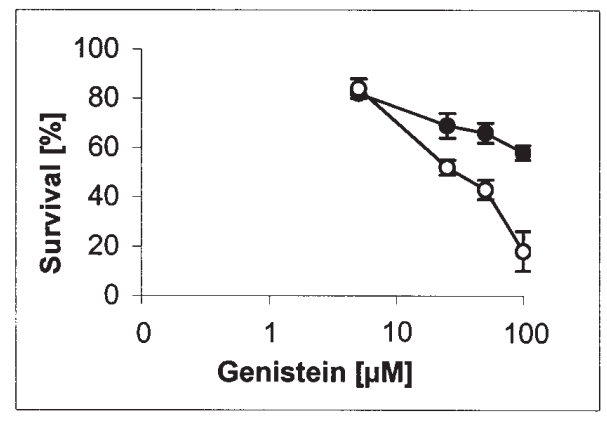

Figure 5. Genistein-induced apoptosis is attenuated by BCL-2. LNT-229 cells transfected with neo (white circles) or BCL-2 (black circles) were exposed to genistein for $72 \mathrm{~h}$. Survival was assessed by crystal violet staining. Data are expressed as mean percentages $(n=3)$.

The temperature-sensitive murine $\mathrm{p} 53^{\mathrm{V} 135 \mathrm{~A}}$ was introduced into the LN-18 and LNT-229 cells to examine the modulation of genistein by altering the p53 status. At $38.5^{\circ} \mathrm{C}, \mathrm{p} 53^{\mathrm{v} 135 \mathrm{~A}}$ behaves as a dominant-negative mutant but at $32.5^{\circ} \mathrm{C}$, p53 $3^{\mathrm{V} 135 \mathrm{~A}}$ assumes many wild-type properties in glioma cells. LNT-229 cells are wild-type for p53 whereas LN-18 cells are mutant for $\mathrm{p} 53$. The ectopic expression of the temperaturesensitive $5^{5} 3^{\mathrm{V} 135 \mathrm{~A}}$ had no effect on genistein cytotoxicity in LN-18 or LNT-229 cells at either temperature (Fig. 4).

Genistein-induced apoptosis in glioma cells is modulated by the ectopic expression of BCL-2, though not by the ectopic expression of crmA. To characterize glioma cell death induced by genistein, we investigated whether the effects of genistein were modulated by the ectopic expression of the anti-apoptotic BCL-2 protein, the ectopic expression of the preferential caspase 1/8 inhibitor, crm-A, or co-exposure to the pan-specific pseudosubstrate caspase inhibitor, zVAD-fmk, or the caspase 3 inhibitor, zDEVD-fmk. Genistein-induced cell death was attenuated by BCL-2 (Fig. 5) whereas the expression of crmA did not modulate genistein-induced cell death (data not shown). To further assess the role of caspases in genistein-induced cell death, LNT-229 cells were co-exposed to increasing concentrations of genistein $(10,50$ and $100 \mu \mathrm{M})$ in the presence of zVAD-fmk or zDEVD-fmk (20, 100 and

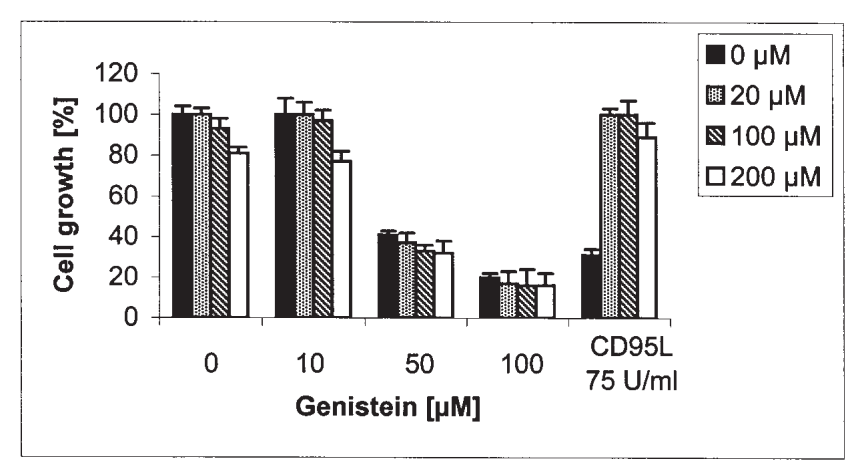

Figure 6. No role for caspases in genistein-induced cell death. LNT-229 cells were co-exposed to genistein $(10,50$ and $100 \mu \mathrm{M})$ and zVAD-fmk $(20,100$ and $200 \mu \mathrm{M}$ ) for $72 \mathrm{~h}$. Exposure to CD95L (75 U/ml) was used as a positive control. Survival was assessed by crystal violet staining. Data are expressed as mean percentages $(n=3)$.

$200 \mu \mathrm{M})$ for $72 \mathrm{~h}$. Exposure to CD95L (75 U/ml) was used as a positive control. The cytotoxic effects of genistein were not attenuated at any concentration of the caspase inhibitor zVAD-fmk (Fig. 6) or the caspase 3 inhibitor zDEVD-fmk (data not shown).

Genistein induces a cleavable complex formation in human malignant glioma cells. Previous studies performed in our laboratory have confirmed that teniposide induced cleavable complexes of DNA and topoisomerase II. After exposure to genistein $(100 \mu \mathrm{M}, 30 \mathrm{~min})$ the cleavable complex formation was also detected (Fig. 7), suggesting that topoisomerase II serves as a target of genistein in glioma cells.

Genistein fails to alter drug sensitivity or susceptibility to CD95L-induced apoptosis in glioma cells. To assess the modulation of drug cytotoxicity by genistein, LNT-229 and T98G cells were pre-exposed to genistein for $48 \mathrm{~h}$ and then co-exposed to various concentrations of topotecan, cisplatin, CCNU or cytarabine for another $48 \mathrm{~h}$. Genistein $(10$ or $50 \mu \mathrm{M})$ failed to induce cell death in synergy with any of the drugs. Furthermore, pre- or co-exposure to genistein neither inhibited nor enhanced glioma cell vulnerability to exogenous CD95Lmediated apoptosis. Representative data are shown in Fig. 8. 


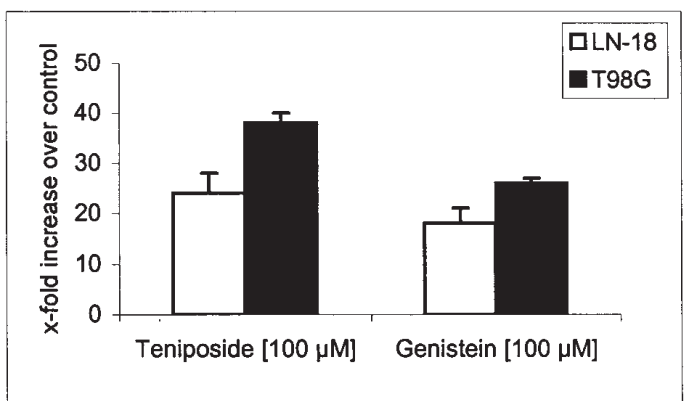

Figure 7. Cleavable complex formation after exposure to genistein. LN-18 (white bars) or T98G (black bars) human glioma cells were exposed to teniposide $(100 \mu \mathrm{M})$ or genistein $(100 \mu \mathrm{M})$ for $30 \mathrm{~min}$. The cleavable DNA topoisomerase II complex formation was assessed as previously described (16). Data are expressed as an $x$-fold increase over the control (untreated cells).

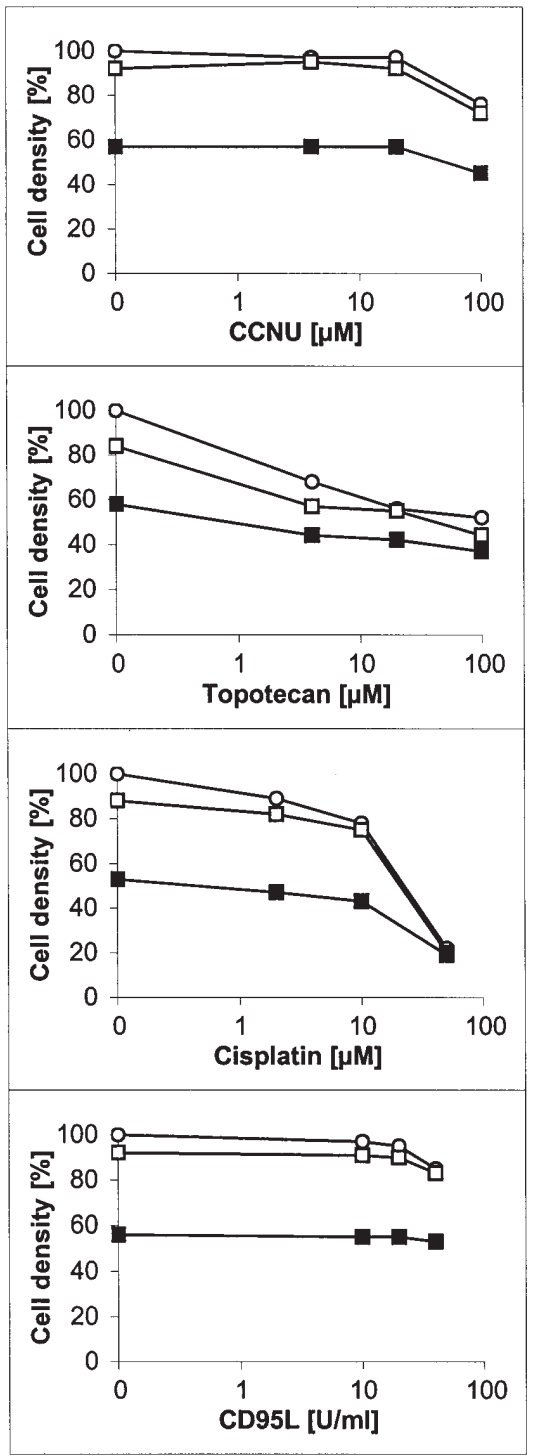

Figure 8. Genistein failed to alter glioma cell susceptibility to cancer chemotherapy or CD95L. LNT-229 cells seeded in 96-well plates $\left(5 \times 10^{3}\right.$ cells/ well) were not pretreated (white circles) or pre-exposed to $10 \mu \mathrm{M}$ (white squares) or $50 \mu \mathrm{M}$ (black squares) genistein for $48 \mathrm{~h}$, and subsequently coexposed to these agents and CCNU, topotecan, cisplatin or CD95L for another $48 \mathrm{~h}$. Survival was assessed by crystal violet staining. Data are expressed as mean percentages of survival $(n=3, S E M<10 \%)$.

\section{Discussion}

Defining novel treatments for malignant gliomas is an urgent medical need. This includes the large-scale screening of synthetic and natural compounds. One such natural compound with antitumor properties is genistein $(1,18-20)$. We found that genistein is cytotoxic to all of the four glioma cell lines tested. Growth inhibition detected by crystal violet staining was a result of cell cycle arrest without differentiation and drug-induced cell death. Electron microscopy confirmed the lack of differentiation of genistein-treated glioma cells and showed classical apoptosis to be the mode of cell death in response to higher concentrations of genistein (Fig. 2). These findings are consistent with previous observations where apoptosis was seen only in higher concentrations of genistein in various cancer cell lines $(1,2,5)$, although no induction of apoptosis was observed in melanoma (6) and leukaemia cells (3).

Several mechanisms of action of genistein have been proposed, including topoisomerase II inhibition. Salti et al (5) showed that genistein inhibited the activity of DNA topoisomerase II and stabilised the cleavable complex in colon cancer cells. Markovits et al (7) demonstrated the role of genistein as a topoisomerase II inhibitor in lung cells. After LNT-229 was exposed to genistein, a cleavable complex formation was observed (Fig. 7), suggesting that the topoisomerase II inhibition is one of the underlying mechanisms of genistein-induced cytotoxicity in glioma cells .

Genistein was previously shown to induce a G2/M cell cycle arrest in MCF-7 human breast $(1,21)$ as well as in colon cancer cells (5). Consistent with studies in prostate cancer cells (2), we found the up-regulation of p21 (Fig. 3), a cell cycle regulatory protein and $\mathrm{G} 2 / \mathrm{M}$ arrest in genistein-treated glioma cells (Fig. 1C). Using p21-deficient colon carcinoma cells and isogenic control cells, we deduced that the loss of p21 had no effect on the genistein-induced inhibition of proliferation.

The precise molecular pathways mediating genistein cytotoxicity have remained obscure and may be cell typespecific. Wild-type p53 is induced by genistein in MCF-7 breast cancer cells (1) and has been proposed to confer relative resistance to genistein in human melanoma cell lines (6). We found that LNT-229 cells, which retained a wild-type p53 activity (22), exhibited an up-regulation of p53 in response to genistein. However, these cells were no more resistant or sensitive to genistein than the three cell lines (LN-18, T98G and LN-308) which lacked the wild-type p53 activity (Fig. 1). Moreover, the expression of a dominant-negative p53 mutant in LNT-229 cells did not enhance their sensitivity to genistein (Fig. 4). These data indicate that p53 plays no role in the fate of genistein-treated glioma cells.

Previously, caspase 3 activation in genistein-induced apoptosis in testicular cells was observed (23). In contrast, in our studies, genistein-induced cell death in glioma cell lines was unaffected by ectopic expression of the preferential caspase 1/8 inhibitor, crm-A, or co-exposure to zDEVD-fmk or the pan-specific pseudosubstrate caspase inhibitor, zVAD-fmk (Fig. 6). Consequently, genistein-induced cell death seems to be caspase-independent in glioma cells. Notably, however, it was still amenable to inhibition by BCL-2. In contrast to other 
studies (1), BCL-2 expression was not affected by genistein (data not shown).

In contrast to preliminary observations of the synergistic effects of genistein and BCNU in U87 and C6 glioma cells (8), genistein failed to alter glioma cell sensitivity to cancer chemotherapy drugs or CD95L in our study. These data would not support the use of a combination therapy of genistein with conventional drugs in clinical trials.

In conclusion, genistein induces cell cycle arrest and apoptosis in human glioma cell lines, but no differentiation. One underlying mechanism of genistein seems to be topoisomerase II inhibition. The apoptotic cascades induced by genistein are caspase-independent but modulated by the ectopic BCL-2 expression. Genistein failed to be a suitable adjunct to conventional chemotherapy.

\section{References}

1. Constantinou AI, Kamath N and Murley JS: Genistein inactivates bcl-2, delays the $\mathrm{G} 2 / \mathrm{M}$ phase of the cell cycle and induces apoptosis of human breast adenocarcinoma MCF-7 cells. Eur J Cancer 34: 1927-1934, 1998.

2. Davis JN, Singh B, Bhuiyan M and Sarkar FH: Genistein-induced up-regulation of p $21^{\text {waf } 1}$, down-regulation of cyclin B and apoptosis in prostate cancer cells. Nutr Cancer 32: 123-131, 1998.

3. Constantinou AI, Kiguchi K and Huberman E: Induction of differentiation and DNA strand breakage in human HL-60 and K-562 leukemia cells by genistein. Cancer Res 50: 2618-2624, 1990.

4. Lian F, Li Y, Bhuiyan M and Sarkar FH: p53-independent apoptosis induced by genistein in lung cancer cells. Nutr Cancer 33: 125-131, 1999.

5. Salti GI, Grewal S, Mehta RR, Das Gupta TK, Boddie Jr AW and Constantinou AI: Genistein induces apoptosis and topoisomerase II-mediated DNA breakage in colon cancer cells. Eur J Cancer 36: 796-802, 2000.

6. Rauth S, Kichina J and Green A: Inhibition of growth and induction of differentiation of metastatic melanoma cells in vitro by genistein: chemosensitivity is regulated by cellular p53. Br J Cancer 75: 1559-1566, 1997.

7. Markovits J, Linassier C, Fosse P, Couprie J, Pierre J, Jacquemin-Sablon A, Saucier J, Le Pecq J and Larsen AK: Inhibitory effects of the tyrosine kinase inhibitor genistein on mammalian DNA topoisomerase II. Cancer Res 49: 5111-5117, 1989.

8. Khoshyomn S, Nathan D, Manske GC, Osler TM and Penar PL: Synergistic effect of genistein and BCNU on growth inhibition and cytotoxicity of glioblastoma cells. J Neurooncol 57: 193-200, 2002.

9. Zipp F, Martin R, Lichtenfels R, Roth W, Dichgans J, Krammer $\mathrm{PH}$ and Weller $\mathrm{M}$ : Human autoreactive and foreign antigen-specific $\mathrm{T}$ cells resist apoptosis induced by soluble recombinant CD95 ligand. J Immunol 159: 2108-2115, 1997.
10. Weller M, Rieger J, Grimmel C, Van Meir EG, De Tribolet N, Krajewski S, Reed JC, Von Deimling A and Dichgans J: Predicting chemoresistance in human malignant glioma cells: the role of molecular genetic analyses. Int J Cancer 79: 640-644, 1998.

11. Trepel M, Groscurth P, Malipiero U, Gulbins E, Dichgans J and Weller M: Chemosensitivity of human malignant glioma: modulation by p53 gene transfer. J Neurooncol 39: 19-32, 1998.

12. Weller M, Malipiero UV, Aguzzi A, Reed JC and Fontana A Proto-oncogene bcl-2 gene transfer abrogates Fas/APO-1 antibody-mediated apoptosis of human malignant glioma cells and confers resistance to chemotherapeutic drugs and therapeutic irradiation. J Clin Invest 95: 2633-2643, 1995.

13. Wagenknecht B, Schulz JB, Gulbins E and Weller M: Crm-A, bcl-2 and NDGA inhibit CD95L-induced apoptosis of malignant glioma cells at the level of caspase 8 processing. Cell Death Differ 5: 894-900, 1998.

14. Waldman T, Kinzler KW and Vogelstein B: p21 is necessary for the p53-mediated G1 arrest in human cancer cells. Cancer Res 55: 5187-5190, 1995

15. Naumann U, Durka S and Weller M: Dexamethasone-mediated protection from drug toxicity linked to $\mathrm{p} 21^{\mathrm{WAF} / \mathrm{CIP} 1}$ protein accumulation. Oncogene 17: 1567-1575, 1998.

16. Winter S, Roth W, Dichgans J and Weller M: Synergistic activity of CD95 ligand and teniposide (VM26) does not involve enhanced formation of cleavable DNA complexes or changes in CD95/CD95 ligand expression. Eur J Pharmacol 341: 323-328, 1998.

17. Webb JL: Effect of more than one inhibitor. In: Enzyme and Metabolic Inhibitors. Webb JL (ed). Academic Press, New York, pp66-79, 1963.

18. Booth C, Hargreaves DF, Hadfield JA, McGrown AT and Potten CS: Isoflavones inhibit intestinal epithelial cell proliferation and induce apoptosis in vitro. Br J Cancer 80: 1550-1557, 1999

19. Kim H, Peterson TG and Barnes S: Mechanisms of action of the soy isoflavone genistein: emerging role for its effects via transforming growth factor $B$ signaling pathways. Am J Clin Nutr 68: $1418-1425,1998$

20. Puli S, Lai JC and Bhushan A: Inhibition of matrix degrading enzymes and invasion in human glioblastoma (U87MG) cells by isoflavones. J Neurooncol 79: 135-142, 2006.

21. Pagliacci MC, Smacchia M, Migliorati G, Grignani F, Riccardi C and Nicoletti I: Growth-inhibitory effects of the natural phytooestrogen genistein in MCF-7 human breast cancer cells. Eur J Cancer 30: 1675-1682, 1994.

22. Schmidt F, Rieger J, Wischhusen J, Naumann U and Weller M: Glioma cell sensitivity to topotecan: the role of p53 and topotecan-induced DNA damage. Eur J Pharmacol 412: 21-25, 2001.

23. Kumi-Diaka $J$ and Butler A: Caspase-3 protease activation during the process of genistein-induced apoptosis in TM4 testicular cells. Biol Cell 92: 115-124, 2000. 